\title{
Hubungan antara Coping Strategy dengan Parenting Stress pada Ibu yang Memiliki Anak Autis
}

\author{
Febriana Trias Rahmawati ${ }^{1}$ \\ Fakultas Psikologi, Universitas Muhammadiyah Malang \\ e-mail: ${ }^{1}$ febrianatrias@gmail.com
}

\begin{abstract}
Autistic children are not easy to care for. Different treatments, special care for autistic children who have complex conditions different from normal children is what makes parents experience parental stress, especially mothers. One way to deal with maternal parenting stress is by using coping strategies. The purpose of this study was to determine the relationship between coping strategies and parenting stress on mothers with autistic children and to find out how strong the relationship of coping strategies is problem focused coping with emotion focused coping to the level of parenting stress in mothers with autistic children. This research is a quantitative correlational study using the subject of 60 mothers who have autistic children. The sampling technique used is sampling quota where the sampling technique is determined from a population that has certain characteristics to the desired number (quota). This research method uses 2 scales, namely Brief COPE and PSISF. While the data analysis used in this study isanalysis product moment using SPSS 25. The results obtained a significant value of $0.01<0.05$ and $r$ value of 0.601 which means there is a positive relationship between coping strategies with parenting stress in mothers who have autistic children. The contribution of coping strategies to parenting stress is $36.1 \%$.
\end{abstract}

KEYWORDS Coping strategy, parenting stress, autism

CITATION Rahmawati, F. (2019). Hubungan antara coping strategy dengan parenting stress pada ibu yang memiliki anak autis. Cognicia, 7, (1), 121-138.

Kehadiran anak didalam sebuah kehidupan keluarga sangat didambakan oleh pasangan suami istri. Kehadirannya membuat suasana keluarga menjadi menyenangkan. Orangtua berharap anak yang dilahirkan normal dan tumbuh menjadi anak yang sehat jasmani maupun rohani. Sayangnya, tidak semua orangtua dikaruniai anak yang sehat. Terkadang orangtua dikaruniai dengan anak berkebutuhan khusus. Anak berkebutuhan khusus merupakan anak yang memiliki beberapa kekurangan seperti keterbelakangan mental, kesulitan belajar, gangguan emosional, keterbatasan fisik, gangguan bahasa dan bicara, kerusakan pendengaran, penglihatan ataupun memiliki bakat khusus (Aggreni, 2015). Adapun contoh dari anak berkebutuhan khusus adalah autis.

Anak autis adalah gangguan proses perkembangan yang muncul di awal masa kanakkanak dengan efek yang parah dan jangka panjang untuk individu yang terkena dampak dan keluarga mereka (N Somashekar, 2017). ASD (Autism Spectrum Disorder) mengacu pada berbagai kondisi yang ditandai oleh beberapa tingkat perilaku sosial, komunikasi dan bahasa yang terganggu, dan rentang minat dan aktivitas yang sempit 
bagi individu dan dilakukan berulangulang (Organizatio, 2017). Sekarang dianggap sebagai gangguan perkembangan yang paling umum. Jumlah penderita autism di Indonesia pada tahun 2015 diperkirakan mencapai 12.800 anak dan 134.000 menyandang spectrum autism. Penyandang autisme Indonesia diprediksi 2,4 juta orang dengan pertambahan 500 orang per tahun (Nasional, 2018). Data tersebut menunjukkan adanya peningkatan penyandang autis sehingga akan memungkinkan meningkatnya tantangan orangtua dalam proses pengasuhan (parenting).

Parenting yang dilakukan oleh orangtua yang memiliki anak autis tidaklah mudah. Parenting bagi anak autis perlu adanya perlakuan yang berbeda daripada anak pada umumnya. Perlakuan yang berbeda, perawatan yang khusus bagi anak autis yang memiliki kondisi yang kompleks berbeda dari anak normal inilah yang membuat orangtua stres. Istilah "Stres" mengacu pada pengalaman emosional negatif disertai dengan perubahan fisiologis, kognitif, dan perilaku yang dapat diprediksi, yang mengarah pada perubahan dalam memahami situasi dan kemampuan yang menekan untuk dihadapi (Bawalsah, 2016). Definisi ini berimplikasi pada persepsi individu terhadap stres tergantung pada penjelasan pribadi dari situasi tersebut, yaitu stress muncul dari proses kognitif oleh individu untuk mengevaluasi potensi pribadinya untuk menentukan apakah mereka cukup untuk menghadapi tuntutan situasi stres (Bawalsah, 2016).

Orangtua yang mengalami stres dalam proses pengasuhan atau biasa disebut parenting stress yang merupakan serangkaian proses yang membawa pada kondisi psikologis yang tidak disukai dan reaksi psikologis yang muncul dalam upaya beradaptasi dengan tuntutan peran sebagai orangtua (Lestari, 2016). Menurut Abidin (1995) Stres pengasuhan dianggap sebagai reaksi psikologis yang bertentangan terhadap tuntutan menjadi orangtua yang berasal dari kombinasi kompleks yang terkait dengan anak, orangtua dan interaksi anakorangtua.Stres pada orangtua itu selalu berkepanjangan. Selama di dalam keluarga terdapat seorang anak, pemicu stress pada orangtua pasti ada karena pada proses pertumbuhan dan perkembangan anak diperlukan adanya figure seperti orangtua.

Berdasarkan hasil studi lapang dari peneliti pada bulan Januari 2019 mengenai parenting stress pada ibu yang memiliki anak autis ditemukan bahwa masih banyak ibu mengalami kebingungan dalam menghadapi anaknya ketika mengalami emosi yang kurang stabil atau tantrum. Selain itu, masih banyak ibu tidak memberikan perawatan khusus untuk anaknya seperti mengikuti terapi khusus anak autis dikarenakan salah satunya faktor ekonomi yang kurang sehingga belum mampu memenuhi kebutuhan anaknya dengan baik. Peneliti juga menemukan bahwa masih ada ibu yang kurang memberikan kasih sayang kepada anaknya seperti terlihat kurang adanya penerimaan diri ibu terhadap kondisi anaknya.

Selain itu, fenomena yang terjadi ketika ibu mengalami parenting stress terdapat dalam surat kabar diantaranya bahwa ada ibu yang menyiksa anaknya seperti menyeret anaknya yang meringkuk di trotoar menggunakan tali. Kondisis anak tersebut autis yang parah dan emosinya sangat tidak labil sehingga kekerasanlah yang dilakukan ibunya tersebut (Febrida, 2017). Banyak orangtua yang merasa ketakutan anaknya akan terlahir autis. Bahkan banyak pula yang merasa malu dan akhirnya menelantarkan anaknya begitu saja atau bahkan ada yang dipasung (Health, 2010). Ibu 
yang memiliki anak autis terkadang kurang mendapatkan dukungan dari orang lain malah melakukan halhal yang tidak layak untuk diberikan seperti anak autis yang dibully atau dianiaya oleh teman sebayanya seperti ditemukan benjolah di kepalanya sehingga anak autis tersebut meninggal (Safutra, 2017). Hal tersebut merupakan beberapa contoh bentuk parenting stress pada ibu yang memiliki anak autis.

Adapun menurut penelitian yang dilakukan oleh Francesca Cuzzocrea, Anna Maria Murdaca, Sebastiano Costa, Pina Filippello \& Rosalba Larcan (2016) menyatakan bahwa tingkat stres pada orangtua yang memiliki anak autis lebih tinggi daripada tingkat stres pada orangtua yang memiliki anak Down Syndrome dan anak normal. Hal tersebut juga didukung oleh penelitian N. Somasekhar (2017) yang menyatakan bahwa orangtua yang memiliki anak autis mengalami stres yang tinggi daripada orangtua yang memiliki anak retardasi mental.

Orangtua dalam hal ini meliputi ayah dan ibu. Terdapat sebuah penelitian oleh Nishi Tripathi (2015) yang menyatakan bahwa 70\% ibu yang memiliki anak autis mengalami tingkat stress yang lebih tinggi daripada ayah yang memiliki anak autis. Hal ini dikarenakan para ibu biasanya lebih terlibat dalam pengasuhan anak daripada para ayah lebih banyak bekerja lebih keras untuk mendukung kebutuhan keuangan keluarga mereka. Tingginya stress pengasuhan yang dialami oleh orangtua khususnya ibu yang memiliki anak berkebutuhan khusus khususnya autis dapat dipengaruhi oleh beberapa aspek.

Aspek dari stres pengasuhan menurut Abidin (1995) yaitu Parent domain, Child domain, dan ParentChild relationship. Aspek Parent domain dimana tinggi rendahnya stres pengasuhan dapat dipengaruhi oleh aspek dari orangtua itu sendiri diantaranya perasaaan orangtua mengenai kemampuan mereka merawat anak, perasaan kurang adanya dukungan sosial, reaksi orangtua terhadap kebutuhan anaknya, perasaan bersalah, depresi dan sebagainya. Selain itu, terdapat aspek Child domain dimana aspek ini melihat dari anak berkebutuhan khusus tersebut diantaranya kemampuan anak dalam beradaptasi dengan lingkungannya, permintaan anak yang selalu membutuhan bantuan, emosi anak, anak yang sulit mematuhi perintah dan sebagainya. Aspek terakhir yaitu aspek ParentChild relationship dimana perasaan orangtua yang merasa tidak adanya penguatan positif dari anaknya, kondisi anak yang tidak sesuai harapan orangtua, tidak adanya kelekatan antara orangtua dengan anak dan sebagainya.

Selain ketiga aspek yang dapat mempengaruhi tinggi rendahnya stres pengasuhan, terdapat beberapa faktor yang menyebabkan ibu mengalami stres. Beberapa faktor tersebut terbagi dalam empat ruang lingkup utama yaitu tuntutan, kemampuan internal, sumber daya eksternal dan penilaian (Weiss, Wingsiong and Lunsky, 2014). Faktor pertama yaitu "tuntutan" dimana stres itu muncul karena dihadapkan dengan berbagai tuntutan yang berasal dari berbagai faktor diantaranya masalah kesehatan, masalah emosional anak, perawatan, perilaku anak, masalah disekolah dan sebagainya. Salah satu faktor dari tuntutan adalah masalah kesehatan misalnya banyak anak autis yang memiliki fisik yang rentan sakit yang pada akhirnya harus di rawat di rumah sakit dan hal tersebut sering terjadi ketika di situasi tertentu. Inilah yang membuat orangtua memiliki perasaan gelisah, khawatir dan akhirnya memicu orangtua stres. 
Perilaku anak juga dapat mempengaruhi parenting stress dimana tingkah laku anak yang belum bisa dikendalikan oleh dirinya sendiri dan perlu adanya pengawasan dari orangtua. Sehingga banyak waktu orangtua yang digunakan untuk anak daripada aktivitas diluar misalnya waktu yang seharusnya digunakan untuk berkumpul dengan temanteman atau waktu istirahat tidak lagi bisa dilakukan oleh orangtua yang memiliki anak autis. Perilaku anak yang dapat memunculkan emosi yang tidak stabil dapat membuat orangtua mengalami tekanan batin, kecewa, sedih dan mungkin akan merasa marah. Ketika anakanak memasuki masa sekolah, masalah perilaku anak pun hadir dalam lingkungan sekolah. Anakanak autis bisa menjadi sasaran bullying bagi anak normal selain itu dari prestasi anak yang sulit mengikuti pembelajaran anak pada umumnya.

Faktor kedua yaitu "kemampuan internal" ini mengacu pada kemampuan coping yang dimiliki oleh orangtua khusunya ibu. Ketika ibu tidak mampu mengatasi kesulitan yang dialaminya dalam proses pengasuhan, maka ibu akan merasa bahwa dirinya belum kompeten dan hal tersebut akan membuat orangtua kebingungan dan stress. Faktor lain yang dapat memicu stres orangtua adalah kemampuan eksternal sebagai contoh kurang adanya dukungan dari orang lain baik itu dari saudara ataupun pemerintah. Orangtua yang memiliki anak autis perlu adanya dukungan yang positif dari orang orang disekitarnya untuk mampu menjalani kehidupan dalam mengasuh anak mereka.

Selain itu, orangtua yang memiliki perekonomian yang dalam kategori menengah kebawah bisa memicu adanya parenting stress. Jika orang tua dan keluarga tidak didukung dalam memenuhi kebutuhan mereka, itu dapat lebih mengganggu perkembangan seorang anak, yang pada gilirannya akan menciptakan situasi yang menekan untuk orang tua dan keluarga (Bonab, Motamedi and Zare, 2017). Karena ketidakpastian dari ketidakmampuan seperti itu, orang tua dari anakanak dengan autisme dapat mengalami perasaan putus asa dan oleh karena itu menjadi lebih sensitif terhadap peristiwa yang menimbulkan stres.

Faktor terakhir yang dapat memicu stress orangtua adalah "Subjective appraisal" dimana orangtua yang khusunya ibu membuat penilai subjektif tentang status kehidupan mereka dan persepsi mereka tentang tantangan kehidupan mereka dengan mengasuh anak autis. Para ibu mempersepsikan kehidupan yang mereka yakini dapat mengakibatkan tingkat stress yang tinggi, intensitas emosi negatif (Weiss, Wingsiong and Lunsky, 2014). Orangtua menggambarkan kesulitan dalam kehidupan mereka seperti pekerjaan, kesehatan, kematian, gangguan perkawinan, dan keuangan tetapi dengan penekanan pada emosi mereka daripada kejadian itu sendiri. stress orangtua alami seperti perasaan frustrasi, ketidakstabilan emosi, apati, kecemasan, dan kepanikan.

Situasi Stres yang dialami orangtua yang memiliki anak autis bermanfaat bagi perkembangan individu menjadi pribadi yang matang. Saat situasi stres muncul, yang perlu dilakukan adalah menghadapi dan mengelolanya agar membuahkan hasil yang positif (Lestari, 2016). Tingkatan stres pengasuhan tampaknya terkait dengan salah satu faktor internal yang telah dijelaskan sebelumnya yaitu penggunaan coping yang digunakan oleh orangtua dalam pengasuhan. Orangtua yang menggunakan gaya coping disfungsional lebih tinggi tingkat stres pengasuhannya, sementara stress yang 
dialami oleh orangtua akan berkurang apabila dapat menggunakan coping yang efektif (Cuzzocrea et al., 2016).

Coping yang efektif membutuhan strategi yang sesuai dengan situasi yang dihadapi saat proses pengasuhan. Menurut Lazarus dan Folkman (dalam Rantanen et al., 2011) mendefinisikan Coping sebagai upaya kognitif dan perilaku yang terus berubah untuk mengelola tuntutan eksternal dan / atau internal tertentu yang dinilai telah melebihi sumber daya orang tersebut. Sedangkan Coping strategy merupakan suatu usaha yang digunakan untuk memecahkan situasi stress (Bawalsah, 2016). Strategi untuk menghadapi stres dibedakan menjadi dua, yaitu coping strategy yang berfokus pada masalah atau emosi (problemand emotionfocused coping) dan coping strategy dengan cara mendekati atau menghindari stress (approach vs. avoidant coping) (Lestari, 2016). Problem Focused Coping merupakan usaha untuk melakukan apa yang dipercaya individu yang dapat mempengaruhi stress atau situasi yang menekan seperti evaluasi, interpretasi. Emotion Focused Coping merupakan usaha untuk mengatur emosi yang dihasilkan dari situasi yang menekan atau stres seperti perasaan tidak mampu mengubah situasi, kemarahan, kecemasan, keputusaan dan sebagainya (Bawalsah, 2016).

Menurut Picci (Bawalsah, 2016), pengalaman masa lalu, dukungan sosial yang dirasakan, sifat situasi stres adalah contoh faktor yang mempengaruhi strategi coping. Lopes (Bawalsah, 2016) juga menunjukkan bahwa sifat situasi yang menegangkan dapat menentukan jenis strategi yang digunakan untuk mengatasi, yaitu individu cenderung menggunakan strategi yang berfokus pada emosi dalam situasi di mana mereka tidak mampu memberikan upaya langsung untuk menangani situasi ini seperti masalah kesehatan, sementara mereka cenderung menggunakan strategi yang berfokus pada masalah dalam situasi dimana mereka dapat menangani dan mengendalikan, seperti konflik keluarga. Faktor usia juga mempengaruhi strategi coping dimana semakin tinggi usia maka semakin tinggi pula kemampuan orangtua dalam memenuhi tuntutan kehidupan (Mintari, 2003).

Selain itu faktor jenis kelamin juga mempengaruhi penggunaan strategi coping dimana pria dan wanita memiliki caranya sendiri dalam menghadapi permasalahan (Smet dalam Mintari, 2003). Pria lebih rasional dan tenang daripada wanita yang lebih menggunakan perasaan dalam menghadapi masalah. Status sosial dan pendidikan juga mempengaruhi strategi coping. Status sosial yang tinggi lebih menggunakan strategi coping yang adaptif (Haan dalam Mintari, 2003). Status pendidikan yang tinggi cenderung menggunakan problem focused coping ( Billing \& Moos dalam Mintari, 2003).

Jika seorang individu memiliki potensi yang cukup untuk mengatasi situasi yang menekan, kita mengharapkan tingkat stres yang rendah, jika potensi ini kurang dibutuhkan, atau individu percaya bahwa banyak upaya harus disiapkan untuk menghadapi situasi yang penuh tekanan, tingkat stres yang tinggi kemungkinan besar akan terjadi. Mengatasi situasi stres yang berada di luar kendali seseorang adalah salah satu tantangan terbesar dalam hidup. Tanpa ruang lingkup untuk mengurangi atau menghilangkan sumber stres, situasi semacam itu membutuhkan strategi dimana seseorang mengubah diri agar sesuai dengan situasi. Memahami caracara mengatasi 
keluarga sangat penting, karena ini merupakan pusat model kognitif stres dan coping sering diterapkan pada keluarga yang memiliki anak autis.

Coping yang dilakukan oleh orangtua tidaklah semua aktif mendukung kegiatan dan aktivitas anak. Banyak orang tua yang pasif dalam strategi mengurus anak autis, perilaku tersebut dilakukan oleh orang tua yang menyakini bahwa tidak memiliki kemampuan untuk mengubah gangguan anak. Tujuan dari coping strategies adalah untuk memperkuat atau mempertahankan sumber daya keluarga, mengurangi sumber stres atau emosi negatif, dan mencapai keseimbangan dalam fungsi keluarga. Coping yang secara langsung ditujukan untuk mengatasi sumber stres, seperti pemecahan masalah dan mencari informasi adalah strategi yang lebih adaptif daripada upayaupaya untuk menolak atau meminimalkan situasi (Bonab, Motamedi and Zare, 2017). Mengatasi adalah usaha keluarga untuk mengelola atau menghadapi situasi yang menekan. Penting bagi keluarga belajar bagaimana menangani stres mereka secara efektif untuk menghindari konsekuensi psikologis, emosional, dan fisik negatif.

Menurut penelitian terdahulu yang dilakukan oleh Francesca Cuzzocrea, Anna Maria Murdaca, Sebastiano Costa, Pina Filippello \& Rosalba Larcan (2016) menyatakan bahwa coping strategies yang digunakan oleh ibu yang memiliki anak autis kategori rendah lebih banyak memakai avoidant coping. Avoidant coping dilakukan dengan menyangkal stress secara kognitif (Lestari, 2016). Misalnya orangtua melakukan katarsis atau pelepasan emosi sebagai upaya untuk mengurangi distress, perasaan marah, atau perasaan negatif lainnya. Adapun dari penelitian lain menjelaskan bahwa coping strategies yang paling digunakan oleh ibu yang memiliki anak berkebutuhan khusus adalah problem focused engagement (Bawalsah, 2016). Hal tersebut juga diteliti oleh Arshia Shahbaz dan Dr. Shazia Hasan (2017) bahwa Tingkat stres yang lebih tinggi dialami orang tua yang terlibat dalam menggunakan strategi yang berfokus pada emosi daripada strategi yang berfokus pada masalah. Oleh karena itu, keluarga cenderung untuk mengatasi lebih baik sambil mengikuti strategi yang berfokus pada masalah daripada yang berfokus pada emosi.

Berdasarkan latar belakang tersebut, peneliti ingin meneliti hubungan antara coping strategies dengan parenting stress pada ibu yang memiliki anak autis. Penelitian mengenai hal tersebut belum banyak di teliti di Indonesia. Penelitian yang telah dilakukan di Indonesia kebanyakan hanya memakai metode kualitatif dengan pendekatan fenomenologis seperti yang dilakukan oleh Zain Nur Choirul Nisa (2017) yang tujuan penelitiannya untuk mendeskripsikan strategi coping orang tua yang memiliki anak autis. Selain itu, peneliti ingin mengetahui seberapa kuat hubungannya dari aspek coping strategies yaitu problem focused coping dengan emotion focused coping terhadap tingkat parenting stress pada ibu yang memiliki anak autis. Oleh karena itu peneliti ingin melakukan penelitian mengenai hubungan antara coping strategies dengan parenting stress pada ibu yang memiliki anak autis dimana penelitian ini menggunakan metode kuantitatif dengan menggunakan skala the Coping Strategies Inventory Short Form (CSISF) yang diadaptasi dari penelitian oleh Clifton C. Addison, Brenda W. CampbellJenkins, Daniel F. Sarpong, Jeffery Kibler, Madhu Singh, Patricia Dubbert, Gregory Wilson, Thomas Payne and Herman Taylor (2007) yang terdiri dari 16 item untuk mengukur strategi coping serta skala Parenting Stress Index Short Form (PSISF) yang terdiri dari 36 item. Tujuan dari penelitian ini adalah untuk mengetahui 
hubungan coping strategies dengan stres pengasuhan bagi ibu yang memiliki anak autis. Manfaat dari penelitian ini semoga bisa memberikan sumbangan dalam pengembangan ilmu pengetahuan dan sebagai rekomendasi dibidang keilmuan psikologi terutama psikologi keluarga.

\section{METODE}

Penelitian ini menggunakan metode penelitian kuantitatif yang dimana metode ini berlandaskan pada filsafat positivisme yang digunakan untuk meneliti populasi atau sampel tertentu, pengumpulan data menggunakan instrument penelitian, analisis data bersifat statistic, dengan tujuan untuk menguji hipotesis yang telah ditetapkan (Sugiyono, 2015). Alasan peneliti menggunakan jenis penelitian kuantitatif karena dalam penelitian ini menggunakan alat ukur atau instrument untuk menguji hipotesis yang telah ditetapkan. Desain penelitian ini adalah penelitian korelasional dimana Penelitian ini bertujuan untuk mengetahui hubungan antara variable $\mathrm{X}$ (Independent) dengan variable $\mathrm{Y}$ (Dependent). Penelitian ini menggunakan jenis penelitian korelasional karena peneliti ingin mengetahui hubungan coping strategies dengan parenting stress pada ibu yang memiliki anak autis.

Menurut Sugiyono (2015) populasi adalah wilayah generasi yang mencakup subjek yang mempunyai kualitas dan karakteristik yang telah ditetapkan oleh peneliti. Sampel adalah bagian dari populasi tersebut. Teknik pengambilan sampel dalam penelitian ini menggunakan teknik nonprobability sampling dimana teknik pengambilan sampel ini tidak memberi peluang yang sama bagi setiap anggota populasinya. Teknik nonprobability sampling yang digunakan dalam penelitian ini adalah sampling kuota yang mana teknik pengambilan sampel ditentukan dari populasi yang mempunyai ciri-ciri tertentu sampai jumlah (kuota) yang diinginkan. Alasan peneliti menggunakan teknik sampling kuota karena subjek yang digunakan peneliti yaitu ibu yang memiliki anak autis terbatas sehingga sampling kuota dapat mempermudah peneliti dalam mencari subjek. Penentuan jumlah subjek berdasarkan sugiyono (2015) yang menyatakan bahwa minimal 30 subjek. Hal tersebut juga diperkuat oleh teori Gravetter dan Wallnau (2013) menyatakan bahwa minimal jumlah sampel yang diperlukan 30 untuk mendekati distribusi data normal. Sehingga subjek penelitian ini berjumlah 60 dari dua kali lipat jumlah minimal. Subjek penelitian yang digunakan berasal dari beberapa sekolah inklusi dan sekolah luar biasa yang berada di Malang dan Batu. Diantaranya SDN Mojorejo Batu, SDN Junrejo 1 Batu, SDN Junrerjo 2 Batu, SDN Tlekung 1 Batu, SDN Tlekung 2 Batu, SDN Punten 1 Batu, SLB Idaayu 2 Malang, SLB Sumber Dharma Malang, SLB Negeri Batu, SLB Eka Mandiri, SLB Autis UM dan sebagainya. Adapun kirteria ibu yang digunakan dalam peneliti ini adalah ibu yang memiliki anak autis sesuai dengan judul penelitian ini.

Penelitian ini terdapat dua variabel yaitu variabel $X$ (independent /variabel yang mempengaruhi) adalah coping strategies serta variable $Y$ (Dependent / variabel yang dipengaruhi) adalah parenting stress. Definisi Operasional dari coping strategies dalam penelitian ini adalah cara efektif yang dilakukan ibu dalam mengasuh anak autis dengan berfokus pada masalah dimana ibu membuat rencana, mencari dan melakukan halhal untuk mengasuh anak serta berfokus pada emosi dimana ibu mendekatkan diri kepada Allah, mencari hikmah positif, meregulasi perasaan, mencari 
dukungan dari orang lain dan mencari harapan positif ketika mengasuh anak. Sedangkan definisi operasional dari parenting stress adalah proses yang menghasilkan perasaan negatif yang muncul dalam upaya untuk menjalankan peran sebagai orangtua diantaranya yaitu persepsi orangtua terhadap dirinya sendri, persepsi orangtua terhadap anaknya serta harapan dan interaksi orangtua dengan anaknya.

Alat ukur yang digunakan dalam penelitian ini adalah Brief COPE dan PSISF. Skala Brief COPE digunakan untuk mengukur coping strategies yang digunakan pada ibu yang memiliki anak autis. Brief COPE merupakan skala yang berdasarkan teori dari Lazarus dan Folkman (1984) dan skala ini dari Carver et al. (1997). Skala ini terdiri dari 28 item yang terdiri dari 2 aspek yaitu aspek Problem Focused Coping (6 item) dan Emotion Focused Coping (22 item). Aspek Problem focused coping meliputi active coping, use of instrumental support, planning. Sedangkan Aspek Emotion Focused Coping meliputi Self distraction, substance use, denial, behavioral disangangement, venting, humor, religion, self blame, use of emotional support, positive reframing dan acceptance. Skala yang digunakan adalah skala likert yang disusun dengan item favorable. Pada setiap item memiliki 4 pilihan jawaban yaitu 4 = sangat sering, $3=$ sering, 2 = jarang, 1 = belum pernah. Sedangkan alat ukur PSISF digunakan peneliti untuk mengukur tingkat stres pengasuhan yang dialami pada ibu yang memiliki anak autis. PSISF ini skala yang berlandaskan pada teori Abidin (1995) yang terdiri dari 36 item. Skala ini terdiri dari 3 aspek yaitu aspek parent domain (12 item), child domain (13 item) dan parentchild relationship (11 item). Skala ini juga menggunakan skala likert yang disusun dengan item favorable semua. Pada setiap item memiliki 5 pilihan jawaban yaitu $5=$ SS (Sangat Setuju), 4 = S (Setuju), 3 = R (Ratarata), 2 = TS (Tidak Setuju), 1 = STS (Sangat Tidak Setuju).

Tabel 1. Indeks Validitas dan Reliabilitas Alat Ukur Penelitian

\begin{tabular}{lccc}
\hline \multicolumn{1}{c}{ Alat Ukur } & Jumlah Item Valid & Indeks Validitas & Indeks Reliabilitas \\
\hline Coping Strategies & 17 item & $0.276-0.727$ & 0.862 \\
Parenting Stress & 30 item & $0.221-0.733$ & 0.916 \\
\hline
\end{tabular}

Dari hasil uji validitas dan reliabilitas alat ukur coping strategies dan parenting stress, didapatkan skala coping strategies dari 28 item, terdapat 11 item yang tidak valid dan tidak dapat digunakan sehingga hanya 17 item valid yang mampu mengukur tingkat coping strategies. Indeks validitas alat ukur coping strategies berkisar dari rentang $0.276-0.727$ dan nilai reliabilitas sebesar 0.862 . Sedangkan hasil dari skala parenting stress dari 36 item terdapat 6 item yang tidak valid sehingga terdapat 20 item valid yang mampu mengukur parenting stress subjek. Indeks validitas alat ukur tersebut dari rentang $0.221-0.733$ dan nilai reliabilitas 0.916 .

Penelitian yang akan dilakukan melalui beberapa proses yaitu persiapan, pelaksanaan dan analisa. Tahap persiapan dimulai dari peneliti melakukan pendalaman materi melalui kajian teoritik. Peneliti menyusun dan mengembangkan alat ukur atau mencari alat ukur berdasarkan aspek dalam variabel, selanjutnya peneliti meminta ijin untuk melakukan penelitian. Peneliti menggunakan 60 subjek dengan karakteristik yang sudah ditentukan. Subjek yang diperoleh dari beberapa 
sekolah inklusi dan sekolah luar biasa di daerah Kota Malang dan Batu. Selanjutnya peneliti melakukan analisa data menggunakan Statistical Package For Social Sciense (SPSS) 25 untuk mendapatkan item valid dan reliabel.

Tahap selanjutnya tahap pelaksanaan, pada tahap pelaksanaan peneliti menyebarkan skala pada ibu yang memiliki anak autis dengan kriteria yang telah ditetapkan sebelumnya. Alat ukur disebarkan kepada subjek secara langsung dan tidak langsung untuk memberikan 2 skala yaitu skala coping strategies dan parenting stress.

Terakhir, tahap analisa yaitu menganalisa hasil yang didapapatkan dari penyebaran 2 skala kepada minimal 30 subjek. Data yang telah diperoleh kemudian diinput dan diolah dengan menggunakan program perhitungan statistic SPSS 25, yaitu analisa parametric dengan jenis data interval. Menggunakan analisis korelasi product moment pearson.

\section{HASIL}

Berdasarkan uji kurtosis dan skewness, data dikatakan normal apabila hasil nilai kurtosis dan skewness pada nilai statistic dibagi nilai standart error diantara 2 dan 2. Dari hasil uji normalitas yang dilakukan pada kedua variabel dikatakan normal karena dari variabel coping strategies hasil skewness dari nilai statistik (0.457) dibagi nilai standart error (0.309) adalah 1.479 serta hasil kurtosis dari nilai statistik (0.263) dibagi nilai standart error (0.608) adalah 0.433. Sedangkan variabel parenting stress hasil skewness nilai statistik (0.484) dibagi nilai standart error (0.309) adalah 1.566 serta hasil kurtosis dari nilai statistik ( 0.822 ) dibagi nilai standart error (0.608) adalah 1.352. Kedua variabel memiliki hasil nilai kourtosis dan skewness diantara 2 dan 2.

Tabel 2. Distribusi Data Demografi Ibu dan Anak

\begin{tabular}{llcc}
\hline \multicolumn{1}{c}{ Karakteristik } & F & Persentase \\
\hline Demografi Ibu & & & \\
\hline Usia & $<30$ Tahun & 8 & $13 \%$ \\
& 31 40 Tahun & 26 & $43 \%$ \\
& 41 50 Tahun & 20 & $33 \%$ \\
& $>60$ Tahun & 6 & $10 \%$ \\
\hline Pekerjaan & Ibu Rumah Tangga & 40 & $67 \%$ \\
& Wiraswasta & 13 & $22 \%$ \\
& Pegawai Swasta & 1 & $2 \%$ \\
\hline Pendidikan & SD & 3 & $5 \%$ \\
& SMP & 21 & $35 \%$ \\
& SMA & 25 & $42 \%$ \\
& S1 & 9 & $15 \%$ \\
& S3 & 1 & $2 \%$ \\
\hline Demografi Anak & & & \\
\hline Usia & 5 - 12 Tahun & 45 & $75 \%$ \\
& 13 - 20 Tahun & 15 & $25 \%$ \\
\hline Jenis Kelamin & Lakilaki & 40 & $67 \%$ \\
& Perempuan & 20 & $33 \%$ \\
\hline
\end{tabular}


Berdasarkan tabel 2 menunjukkan data demografi Ibu dan Anak, berdasarkan data demografi ibu yang memiliki anak autis terbanyak usia 31 - 40 tahun yaitu 26 responden ( $43 \%$ ) dan paling banyak ibu bekerja sebagai Ibu rumah tangga yaitu 40 responden $(67 \%)$ serta paling banyak ibu yang memiliki pendidikan terakhir SMA yaitu 25 responden (42\%).

Tabel 3. Kategorisasi Variabel

\begin{tabular}{lccccc}
\hline \multicolumn{1}{c}{ Variabel } & Mean & SD & Rentang & F & Persentase \\
\hline $\begin{array}{l}\text { Coping Strategies } \\
\text { Tinggi }\end{array}$ & 35 & 7 & & & \\
$\quad$ Rendah & & & $35-54$ & 57 & $95 \%$ \\
\hline Problem & 6 & 1 & $6-12$ & 10 & $16 \%$ \\
\hline Emotion & 29 & 7 & $17-44$ & 50 & $84 \%$ \\
\hline Parenting Stress & 79 & 16 & & & \\
$\quad$ Tinggi & & & $78-110$ & 58 & $97 \%$ \\
$\quad$ Rendah & & & $51-77$ & 2 & $3 \%$ \\
\hline
\end{tabular}

Berdasarkan tabel 3 menunjukkan kategorisasi variabel coping strategies yang terdiri dari problem focused coping dan emotion focused coping serta parenting stress. Bahwa sebagian besar responden menggunakan emotion focused coping dengan prosentase sebesar $84 \%$ dan problem focused coping dengan prosentase sebesar $16 \%$. Sedangkan pada variabel parenting stress sebagian besar responden mendapatkan skor yang tinggi dengan persentase sebesar $97 \%$.

Selanjutnya untuk mengetahui ada tidaknya hubungan antara coping strategies dengan parenting stress, peneliti melakukan analisis korelasi product moment pearson. Berikut hasil pengukuran yang diperoleh.

Tabel 4. Deskripsi Uji Korelasi Product Moment Pearson

\begin{tabular}{lccc}
\hline \multicolumn{1}{c}{ Variabel } & $\mathbf{r}$ & $\mathbf{r}^{2}$ & $\mathbf{p}$ \\
\hline $\begin{array}{l}\text { Coping Strategies } \\
\text { Parenting Stress }\end{array}$ & 0.601 & 0.361 & 0.01 \\
\hline
\end{tabular}

Pada table 4 menjelaskan uji korelasi product moment pearson yang menunjukkan hasil uji korelasi nilai signifikasi < 0.05 yaitu sig Coping strategies dengan parenting stress 0.01 . Skor korelasi dari kedua variabel tersebut didapatkan sebesar 0.601 bahwa adanya hubungan positif yang signifikan antara coping strategies dan parenting stress. Hal ini menunjukkan bahwa semakin tinggi coping strategies maka semakin tinggi pula tingkat parenting stress pada ibu yang memiliki anak autis dan sebaliknya. Hasil penelitian tersebut tidak sesuai dengan hipotesa penelitian yang mengatakan bahwa adanya hubungan yang negatif antara coping strategies dengan parenting stress pada ibu yang memiliki anak autis. Selain itu, sumbangan variabel coping strategies terhadap parenting stress sebesar $36.1 \%$. 
Tabel 5. Deskripsi Uji Korelasi Product Moment Pearson Tiap Aspek Coping Strategies

\begin{tabular}{cccc}
\hline Variabel & $\mathbf{r}$ & $\mathbf{r}^{2}$ & $\mathbf{p}$ \\
\hline Problem Focused Coping & 0.218 & 0.047 & 0.047 \\
Emotion Focused Coping & 0.609 & 0.371 & 0.01 \\
\hline
\end{tabular}

Pada tabel 5 menjelaskan uji korelasi product moment pearson pada aspek Coping Strategies terutama pada problem focused coping dengan parenting stress yang menunjukkan hasil korelasi nilai signifikasi $0.047<0.05$ dan nilai $\mathrm{r}$ sebesar 0.218 artinya adanya hubungan yang positif antara problem focused coping dengan parenting stress. Selain itu, sumbangan problem focused coping terhadap parenting stress sebesar $4.7 \%$. Sementara pada skor korelasi antara Emotion Focused Coping dengan parenting stress didapatkan nilai signifikasi $0.01<0.05$ dan nilai $\mathrm{r}$ sebesar 0.609 yang artinya adanya hubungan positif yang signifikan antara Emotion Focused Coping dan parenting stress. Hal ini menunjukkan bahwa semakin tinggi Emotion Focused Coping yang digunakan pada ibu yang memiliki anak autism maka tingkat parenting stress akan meningkat. Selain itu, sumbangan Emotion Focused Coping terhadap parenting stress sebesar $37.1 \%$.

\section{DISKUSI}

Hasil analisa data dari penelitian yang telah dilakukan dapat menunjukkan bahwa tidak adanya hubungan negatif antara coping strategies dengan parenting stress $(\mathrm{r}=0.601)$. Analisa menunjukkan bahwa semakin tinggi coping strategies maka semakin tinggi parenting stress $(\mathrm{p}=0.01<0.05)$. Hasil penelitian ini menolak atau tidak membuktikan hipotesa penelitian yang menyatakan bahwa ada hubungan negatif antara coping strategies dengan parenting stress yang berarti semakin tinggi variabel satu, maka akan menurunkan variabel lain, dan begitu sebaliknya. Namun ada temuan yang menarik bahwa semakin ibu yang memiliki anak autis menggunakan emotion focused coping maka semakin tinggi pula tingkat parenting stress karena skor dari hasil uji korelasi sangat signifikan sebesar $r=0.609$ dan $p=0.01<0.05$.

Menurut Lazarus dan Folkman (1984) mendefinisikan emotion focused coping sebagai proses kognitif misalnya, dari pemikiran positif dan ekspresi emosi, tujuannya adalah untuk mentoleransi situasi yang menekan. Berdasarkan kerangka berfikir peneliti yang berlandaskan teori tersebut dan penelitian terdahulu, bahwa apabila ibu menggunakan emotion focused coping dalam mengasuh anak autis maka halhal yang biasa ibu lakukan meliputi Ibu mendekatkan diri kepada Allah, mengambil hikmah positif yang terjadi pada anaknya, Ibu mampu meregulasi perasaan maupun tindakan tanpa melebihkan sesuatu terhadap masalah, Ibu mencari nasehat dari seseorang untuk mendapatkan dukungan emosional dari orang lain dan Ibu cenderung untuk mencari harapan positif dari keadaan yang menekan. Apabila hal tersebut diterapkan dalam mengasuh anak autis maka akan berdampak pada tiga aspek dari parenting stress.

Aspek pertama yaitu Parent Domain menurut Sa'diyah (2016) Aspek pertama ini terdiri dari adanya perasaan orangtua bahwa dirinya kurang memiliki kemampuan merawat anak, perasaan terisolasi secara sosial dan tidak ada dukungan sosial, orang tua merasa dikuasai oleh kebutuhan dan permintaan anaknya, tidak adanya dukungan 
emosional dan material dari suami, ketidaknyamanan yang dikarenakan oleh gangguan kesehatan, dan orang tua mengalami beberapa gejala depresi dan merasa bersalah. Ibu yang menggunakan emotion focused coping dalam mengasuh anak autis, maka ibu akan mendapatkan dukungan emosional dari keluarga, tetangga dan sebagainya, tidak merasa terbebani dengan kondisi anak, serta meningkatnya perasaan positif pada ibu. Selain itu jika dilihat dari aspek kedua Parenting stress yaitu Child Domain menurut Sa'diyah (2016) aspek kedua ini meliputi persepsi ibu terhadap kemampuan anak dalam beradaptasi dengan lingkungan, permintaan anak untuk selalu dibantu dalam semua aktivitas, anak sering menunjukkan emosi negatif dan anak sulit mengikuti dan menaati perintah. Apabila ibu menggunakan emotion focused coping dalam mengasuh anak autis, maka ibu akan merasa kurang percaya diri terhadap kemampuan anak beradaptasi dengan lingkungan, ibu kurang mampu dalam memenuhi permintaan anak, mengatur emosi anak dan anak sulit mematuhi perintah. Jika dilihat dari aspek ketiga Parenting Stress yaitu Parent Child Interaction yang meliputi orangtua tua merasa tidak ada penguatan positif dari anaknya, yakni kondisi anak yang tidak sesuai dengan harapan akan menimbulkan penolakan orang tua, dan orangtua tidak memiliki kedekatan emosional dengan anaknya. Apabila emotion focused coping diterapkan oleh ibu yang memiliki anak autis maka ibu akan merasa kurang adanya penguatan positif antara anak dengan ibu, meningkatnya penerimaan diri ibu terhadap kondisi anaknya, kurang adanya kelekatan emosional antara anak dengan ibu. Berdasarkan penjelasan diatas dapat disimpulkan bahwa ibu yang menggunakan emotion focused coping dalam mengasuh anak autis akan memberi dampak pada internal ibunya atau afeksi ibu belum tindakan untuk mengasuh anaknya secara langsung. Sedangkan dari hasil penelitian ini, ibu yang memiliki anak autis lebih banyak menggunakan emotion focused coping daripada problem focused coping.

Penyebab hipotesa dari penelitian ini tidak diterima selain yang telah disebutkan sebelumnya adalah ditemukan bahwa dari skor item pada aspek emotion focused coping lebih besar daripada skor dari aspek problem focused coping yang terdapat dalam alat ukur BRIEF COPE dimana untuk mengukur coping strategies. Skor total untuk aspek emotion focused coping sebesar 1768 sedangkan skor total untuk aspek problem focused coping sebesar 349. Jika dilihat dari alat ukur BRIEF COPE yang dibuat oleh Carver berlandaskan Lazarus ini, ditemukan bahwa pada aspek emotion focused coping ini terdapat indikator yang positif dan negatif. Menurut Carver (1989) Emotion focused coping meliputi positive reframing, denial, acceptance, using emotional support, religion, venting, self distraction, behavioral disangangement, substance, self blame dan humor. Terdapat 5 indikator yang termasuk emosi negatif dan 6 indikator yang positif. Skor yang termasuk item emosi negatif (1123) lebih besar daripada skor item emosi positif (645). Adapun indikator yang termasuk dalam emotion focused coping negatif adalah Denial (Penyangkalan) merupakan suatu usaha individu untuk menyangkal bahwa dirinya dihadapkan pada suatu masalah. Selfdistraction (Pengalihan diri) merupakan berbagai aktivitas yang berfungsi untuk mengalihkan perhatian individu dari pemikiran tentang permasalahan yang sedang dihadapi seperti tidur, menonton tv dan sebagainya. Substance use (Penggunaan zat) merupakan usaha individu untuk menghilangkan tekanan dengan melarikan diri pada konsumsi alcohol 
atau obatobatan terlarang. Behavioral disengangement (Perilaku menyimpang) merupakan bentuk coping yang berupa berkurangnya usahausaha yang dilakukan oleh individu dalam mengatasi stressor atau kecenderungan individu menyerah untuk berusaha mencapai tujuan yang terhambat oleh stressor. SelfBlame (Menyalahkan diri sendiri) merupakan mengkritik diri sendiri sebagai penanggungjawab dalam sebuah situasi.

Hal tersebut didukung juga oleh penelitian sebelumnya yang dilakukan oleh A. Dabrowska dan E. Pisula (2010) yang menyatakan bahwa orangtua yang memiliki anak autis lebih banyak menggunakan bentuk emotion focused coping terutama avoidanceoriented coping dan lebih banyak mengalami stress dalam mengasuh anaknya. Selain itu didukung oleh penelitian yang dilakukan oleh Richard P. Hastings (2005) yang menyimpulkan bahwa coping penghindaran aktif yang itu termasuk bentuk emotion focused coping tidak membantu untuk mengatasi tuntutan membesarkan anakanak autis. Hal tersebut juga diteliti oleh Arshia Shahbaz dan Dr. Shazia Hasan (2017) bahwa Tingkat stres yang lebih tinggi dialami orang tua yang terlibat dalam menggunakan strategi yang berfokus pada emosi daripada strategi yang berfokus pada masalah. Selain itu, dalam penelitian yang dilakukan oleh Paul R.Binson (2010), distraction and disengagement coping atau emotion focused coping memberikan efek positif yang signifikan pada tekanan hanya ketika perilaku maladaptif anak kurang parah, sementara tidak memiliki efek pada tekanan ketika perilaku masalah lebih parah. Penelitian tersebut menunjukkan bahwa penggunaan coping strategies yang kurang efektif dapat menjadi masalah bagi ibu yang anaknya autis menunjukkan kesulitan perilaku yang relatif kurang intens. Hal tersebut mendukung penyebab penelitian yang telah dilakukan ini tidak menerima hipotesa yang mengatakan bahwa coping strategies yang tinggi bias menurunkan tingkat parenting stress pada ibu yang memiliki anak autis.

Coping strategies merupakan upaya atau proses kognitif dan perilaku yang digunakan individu untuk menangani situasi yang menekan untuk mengurangi tuntutan internal dan eksternal yang terkait dengan situasi ini, dalam upaya untuk memperoleh keseimbangan psikologis individu yang digunakan untuk hidup sebelumnya (Bawalsah, 2016). Apabila coping strategies itu tidak efektif digunakan oleh ibu yang memiliki anak autis maka tingkat parenting stress akan meningkat dan sebaliknya. Hasil penelitian ini menunjukkan bahwa bentuk emotion focused coping kurang efektif jika digunakan oleh ibu untuk mengasuh anak autis. Karena emotion focused coping hanya mengatasi masalah internal pada diri ibu atau mengatasi emosi ibu saja belum berdampak pada bagaimana ibu mengasuh anak autis atau tindakan langsung untuk mengasuh anak autis. Autisme adalah gangguan yang hadir sejak lahir yang mempengaruhi perilaku manusia seperti interaksi sosial, kemampuan untuk mengkomunikasikan ide dan perasaan, imajinasi, dan menjalin hubungan dengan orang lain (McGEE \& Tipton, 2001). Karena gangguan yang dimiliki oleh anak autis yang kompleks tersebut, maka ibu memerlukan tindakan langsung dalam mengasuh anak autis. Sehingga coping strategies yang lebih efektif digunakan oleh ibu yang memiliki anak autis adalah problem focused coping.

Menurut Lazarus dan Folkman (1984) Problem Focused Coping (PFC) didefinisikan sebagai mengatasi perilaku (Behavioral coping), misalnya membantu mencari dan 
mengambil tindakan langsung dalam situasi yang menantang. PFC berfokuskan pada mendefinisikan masalah, perencanaan, menghasilkan solusi alternatif, menimbang alternatif dalam hal biaya dan manfaat mereka, memilih alternatif, dan bertindak. Berdasarkan kerangka berfikir peneliti, apabila problem focused coping digunakan oleh ibu dalam mengasuh anak autis maka ibu akan melakukan beberapa hal seperti membuat rencana bagaimana merawat anaknya dengan baik, mencari informasi mengenai permasalahan anaknya, serta melakukan halhal untuk mengatasi kesulitan dalam mengatasi anaknya. Apabila hal tersebut dilakukan oleh ibu dalam mengasuh anak autis maka akan berdampak pada tingkai parenting stress yang terdiri dari tiga aspek. Aspek pertama parent domain dimana ibu yang menggunakan problem focused coping akan meningkatkan kepercayaan ibu terhadap kemampuannya dalam merawat anak sehingga bisa merawat anaknya dengan baik. Aspek kedua yaitu Child domain dimana ibu akan meningkat kepercayaannya terhadap kemampuan anak beradaptasi dengan lingkungan, terhadap kemampuan memenuhi permintaan anak, mengatur emosi anak dan anak mampu mematuhi perintah. Aspek ketiga yaitu parentchild interaction dimana ibu yang menggunakan problem focused coping dalam mengasuh anak autis akan mendapatkan penguatan positif antara anak dengan ibu dan meningkatnya kelekatan emosional antara anak dengan ibu. Hal tersebut juga didukung oleh penelitian sebelumnya yang dilakukan oleh oleh Paul R.Binson (2010) bahwa penggunaan problem focused coping dapat mengurangi tingkat parenting stress ibu.

Hasil penelitian ini tidak sesuai dengan hipotesa yang menyatakan bahwa ketika coping strategies tinggi maka tingkat parenting stress menurun seperti penelitian sebelumnya yang dilakukan oleh Latefa All Dardas (2014) dengan menunjukkan hubungan negatif pada coping strategies dan parenting stress yang dialami oleh orangtua yang memiliki anak autis. Pada penelitian tersebut orangtua yang memiliki anak autis menggunakan semua coping strategies mencapai hampir $50 \%$ 70\% dan berpengaruh pada kesehatan mental yang positif. Salah satu penyebab hasil penelitian ini tidak sesuai dengan hipotesa adalah ditemukannya fakta atau faktor lain yang tidak bias dikontrol oleh peneliti seperti tingkat pendidikan ibu yang lebih banyak pada SMA. Tingkat pendidikan merupakan salah satu faktor yang mempengaruhi coping strategies ibu dalam mengasuh anaknya. Hal tersebut sesuai dengan penelitian yang dilakukan oleh Twining Presta Mintari dan Nurlaela Widyarini (2003) yang menyatakan bahwa ada perbedaan coping strategies antara orangtua dengan tingkat pendidikan antara SMP, SMA Diploma dan Sarjana. Semakin tinggi tingkat pendidikan maka akan semakin tinggi pula tingkat kompleksitas kognitifnya dan sebaliknya. Ibu dalam penelitian ini kurang dalam tingkat pendidikannya sehingga coping yang digunakan kurang optimal karena kurang dalam pemikiran rasional atau penilaian terhadap suatu masalah yang dihadapi sehingga bentuk coping yang sering digunakan kurang efektif.

Tingkat pendidikan yang rendah tidak hanya berpengaruh pada coping strategies akan tetapi berpengaruh juga pada tingkat parenting stress pada ibu yang memiliki anak autis. Hal tersebut didukung oleh penelitian yang dilakukan Phetrasuwan, S., \& Shandor Miles, M. (2009) yang menyatakan bahwa Ibu dengan pendidikan rendah dan penghasilan rendah melaporkan lebih banyak stres dalam 
mengasuh anak. Ini mungkin terkait dengan kurangnya akses ke dukungan dan sumber daya lainnya serta tekanan keluarga lainnya. Hal tersebut sesuai dengan hasil penelitian ini dimana aspek parenting stress yang paling tinggi berasal dari parent domain. Aspek Parent domain disebabkan oleh persepsi orangtua terhadap dirinya sendiri. Menurut Sa'diyah (2016) Aspek Parent domain merupakan perasaan orangtua bahwa dirinya kurang memiliki kemampuan merawat anak, perasaan terisolasi secara sosial dan tidak ada dukungan sosial, orang tua merasa dikuasai oleh kebutuhan dan permintaan anaknya, tidak adanya dukungan emosional dan material dari suami, ketidaknyamanan yang dikarenakan oleh gangguan kesehatan, dan orang tua mengalami beberapa gejala depresi dan merasa bersalah.

Oleh karena ibu yang memiliki anak autis dalam penelitian ini memiliki tingkat parenting stress yang tinggi terutama pada aspek parent domain yang dimana adanya perasaan kurang memiliki kemampuan dalam mengasuh anaknya yang disebabkan oleh salah satunya pendidikan yang rendah dan hal tersebut disebabkan coping strategies yang digunakan kurang efektif terutama pada aspek emotion focused coping. Hal ini menunjukkan bahwa tidak semua coping strategies itu efefektif dapat menurunkan tingkat parenting stress pada ibu yang memiliki anak autis. Meskipun emotion focused coping yang digunakan lebih banyak oleh ibu akan tetapi belum tentu menghasilkan efek yang sesuai dengan keinginan ibu dalam mengasuh anak autis.

Adapun keterbatasan penelitian yang telah dilakukan ini adalah kurangnya jumlah subjek penelitian yaitu ibu yang memiliki anak autis. Hal tersebut terjadi karena faktor ketersediaan ibu sebagai subjek penelitian serta faktor perijinan dari pihak sekolah yang terkadang tidak mendapatkan ijin penelitian. Selain itu karena coping strategies itu dipengaruhi oleh banyak faktor dan tergantung dengan masalah yang dihadapi oleh ibu maka keterbatasan penelitian ini adalah faktor demografi yang tidak secara spesifik diteliti oleh peneliti, misalnya kurang selektif dalam memilih usia anak autis.

\section{SIMPULAN DAN IMPLIKASI}

Penelitian ini menunjukkan bahwa ada hubungan positif antara coping strategies dengan parenting stress pada ibu yang memiliki anak autis. Dengan demikian hipotesa penelitian ini tidak terbukti melainkan sebaliknya bahwa semakin tinggi coping strategies maka semakin tinggi pula parenting stress pada ibu yang memiliki anak autis. Namun semakin tinggi ibu yang memiliki anak autis menggunakan emotion focused coping maka semakin tinggi pul tingkat parenting stress.

Implikasi dari penelitian ini yaitu ditemukan bahwa parenting stress pada ibu yang memiliki anak autis tidak bisa diturunkan dengan menggunakan coping strategies yang tinggi terutama emotion focused coping. Jadi diharapkan ibu yang memiliki anak autis menggunakan coping strategies yang sesuai dengan tidak menggunakan lebih banyak emotion focused coping tetapi dengan menggunakan lebih banyak problem focused coping. Untuk penelitian selanjutnya, diharapkan jika ingin melakukan penelitian yang sama, menggunakan jumlah subjek yang lebih banyak supaya bisa melihat rentangan yang lebih besar dan signifikansi yang lebih kecil lagi. Selain itu untuk penelitian selanjutnya disarankan untuk menggunakan analisis yang 
berbeda dari penelitian ini seperti analisis uji beda untuk membedakan strategies coping anak utis dengan anak jenis anak berkebutuhan khusus lainnya.

\section{REFERENSI}

Abidin, R.R. (1995) Parenting Stress Index. Psychological Assessment Resources, Odessa.

Addison, C. C. et al. (2007) 'Psychometric evaluation of a Coping Strategies Inventory ShortForm (CSISF) in the Jackson Heart Study cohort', International Journal of Environmental Research and Public Health, 4(4), pp. 289-295. doi: 10.3390/ijerph200704040004.

Aggreni, M. (2015) 'PENYESUAIAN PSIKOLOGIS ORANGTUA DENGAN ANAK DOWN SYNDROME Ni Made Diah Ayu Anggreni dan Tience Debora Valentina', Universitas Udayana, 2(2), pp. 185-197.

Ali Dardas, L. (2014) 'Stress, Coping Strategies, and Quality of Life among Jordanian Parents of Children with Autistic Disorder', AutismOpen Access, 04(01), pp. 1-6. doi: 10.4172/21657890.1000127.

Amireh, M. M. H. (2018) 'Stress Levels and Coping Strategies among Parents of Children with Autism and Down Syndrome: The Effect of Demographic Variables on Levels of Stress', Child Care in Practice. Taylor \& Francis, 0(0), pp. 1-11. doi: 10.1080/13575279.2018.1446907.

Armajayanthi, E., Victoriana, E. and Ayu, K. L. (2017) 'Studi Deskriptif mengenai Coping Stress pada Ibu yang Memiliki Anak dengan Autism Sebuah Penelitian di Sekolah " X " Bandung', Jurnal Humanitas, 1(1), pp. 37-52. doi: 10.28932/humanitas.v1i1.401.

Bawalsah, J. A. (2016) 'Stress and Coping Strategies in Parents of Children with Physical, Mental, and Hearing Disabilities in Jordan', International Journal of Education, 8(1), p. 1. doi: 10.5296/ije.v8i1.8811.

Benson, P. R. (2010) 'Coping, distress, and wellbeing in mothers of children with autism', Research in Autism Spectrum Disorders, 4(2), pp. 217-228. doi: 10.1016/j.rasd.2009.09.008.

Bonab, B. G., Motamedi, F. and Zare, F. (2017) 'Effect of Coping Strategies on Stress of Parent with Intellectual Disabilities Children', Asian Education Studies, 2(3), p. 11. doi: 10.20849/aes.v2i3.187.

Carver, C., Scheier, M. and Weintraub, J. (1989) 'Assessing Coping Strategies: A Theoretically Based Approach, Journal of Personality and Social Psychology', Journal of Personality and Social Psychology, 56(2), pp. 257-283. doi: 10.1037/00223514.56.2.267.

Charles S. Carver (1997) 'You Want to Measure Coping But Your Protocol's Too Long: Consider the Brief COPE', International Journal of Behavioral Medicine, 4(1), pp. 92-100. doi: 10.1207/s15327558ijbm0401_6.

Cuzzocrea, F. et al. (2016) 'Parental stress, coping strategies and social support in families of children with a disability', Child Care in Practice, 22(1), pp. 3-19. doi: 10.1080/13575279.2015.1064357.

Dabrowska, A. and Pisula, E. (2010) 'Parenting stress and coping styles in mothers and fathers of preschool children with autism and Down syndrome', Journal of Intellectual Disability Research, 54(3), pp. 266-280. doi: 10.1111/j.13652788.2010.01258.x.

Daniels, J. L. (2006) 'Autism and the environment', Environmental Health Perspectives, 114(7). doi: 10.1542/peds.20073000.

Deckard, K. D. (2004). Parenting stress. United States of America: The Composing Room of Michigan, Inc.Espinosa, F. D. et al. (2005) 'Coping strategies in mothers and fathers of preschool and schoolage children with autism', Autism, 9(4), pp. 377-391. doi: $10.1177 / 1362361305056078$.

Exkorn, K. S. (2005). The Autism Sourcebook. United States: HarperCollins Publishers Inc. 
Febrida, M. (2017, 11 28). Kisah di Balik Video Ibu yang Menyeret Anaknya. Retrieved from Hai Bunda.com:

https://www.haibunda.com/kesehatan/d3746369/kisahdibalikvideoibuyangmenyeretanak nya

Fitriani, A. and Ambarini, T. K. (2013) 'Hubungan antara Hardiness dengan Tingkat Stres Pengasuhan pada Ibu dengan Anak Autis', Jurnal Psikologi Klinis dan Kesehatan Mental, 02(1), pp. 34-40. doi: 10.1002/ejoc.201200111.

Gravetter, F. J., \& Wallnau, L. B. (2013). Statistics for the Behavioral Sciences. America: United States.

Hallahan, D. P., \& Kauffman, J. M. (2006). Exceptional Learners. United States: Pearson Education, Inc.

Health, D. (2010, 12 12). Orangtua Tak Perlu Malu Punya Anak Autis. Retrieved from Detik Health: https://health.detik.com/ibudananak/d 1522573/orangtuatakperlumalupunyaanakautis

Hsiao, Y. J. (2018) 'Parental Stress in Families of Children With Disabilities', Intervention in School and Clinic, 53(4), pp. 201-205. doi: 10.1177/1053451217712956.

KATKIĆ, LEJLA OSMANČEVIĆ MOROVIĆ, M. L. and KOVAČIĆ, E. (2017) 'Parenting Stress and a Sense of Competence in Mothers of Children With and Without', Hrvatska revija za rehabilitacijska istraživanja, 53, pp. 63-76.

Kusumastuti, A. N. (2014). Stres Ibu Tunggal Memiliki Anak Autis. Jurnal Psikologi, 7, 5460.

Lazarus, R. S., \& Folkman, S. (1984). Stress, Appraisal, and Coping. New York: Springer Publishing Company.

Lestari, S. (2016). Psikologi Keluarga. Jakarta: Prenadamedia Group.

Maharani, W. O. (Fakultas P. and Margaretha, (Fakultas Psikologi) (2014) 'Stress dan Coping Stress Ibu yang Memiliki Anak dengan Kelainan Hydrocephalus', Jurnal Psikologi Klinis dan Kesehatan Mental, 03(02), pp. 67-71.

McGEE, J. P., \& Tipton, N. (2001). Educating Children with Autism. Washington DC: National Academy Press.

Mintari, T. P. and Widyarini, N. (2003) 'Gambaran Strategi Coping Pada Orang Tua Yang Memiliki Anak Berkebutuhan Khusus (Abk) Twining', Journal of Biological Chemistry, 278(17), pp. 15116-15122.

Nasioanl, H. (2018 , 4 2). Tren Penderita Autisme Meningkat. Retrieved from http://www.harnas.co/2018/04/01/trenpenderitaautismemeningkat

N Somashekar (2017) 'Perceived Stress and Coping Strategies in Parents with Autism', Original Research Paper The International Journal of Indian Psychology ISSN, 4(4), pp. 2348-5396. doi: 10.25215/0404.091.

Neff, K. D. and Faso, D. J. (2015) 'SelfCompassion and WellBeing in Parents of Children with Autism', Mindfulness, 6(4), pp. 938-947. doi: 10.1007/s1267101403592.

Organizatio, W. H. (2017, 4 4). Retrieved from Autism spectrum disorders: http://www.who.int/newsroom/factsheets/detail/autismspectrumdisorders

Paynter, J. et al. (2013) 'The double ABCX model of family adaptation in families of a child with an autism spectrum disorder attending an Australian early intervention service', Research in Autism Spectrum Disorders. Elsevier Ltd, 7(10), pp. 1183-1195. doi: 10.1016/j.rasd.2013.07.006.

Peters, M. F. and Massey, G. (1983) 'Mundane extreme environmental stress in family stress theories: The case of Black families in White America.', Marriage \& Family Review, 6(1-2), pp. 193-218. doi: 10.1300/J002v06n01.

Phetrasuwan, S. and Shandor Miles, M. (2009) 'Parenting Stress in Mothers of Children with Autism Spectrum Disorders', Journal for Specialists in Pediatric Nursing, 14(3), pp. 157-165. doi: 10.1111/j.17446155.2009.00188.x. 
Rantanen, M. et al. (2011) 'Do Individual Coping Strategies Help or Harm in the WorkFamily Conflict Situation? Examining Coping as a Moderator Between WorkFamily Conflict and WellBeing', International Journal of Stress Management, 18(1), pp. 24-48. doi: 10.1037/a0022007.

Safutra, I. (2017, 9 11). Sebelum Meninggal, Anak Autis Ini Sempat Kesakitan di Kepala. Retrieved from JawaPos.com: https://www.jawapos.com/jpgtoday/11/09/2017/sebelummeninggalanakautisinisempatke sakitandikepala

Sa'diyah, S. (2016) 'Gambaran Psychological WellBeing dan Stres Pengasuhan Ibu dengan Anak Autis', SEMINAR ASEAN 2nd PSYCHOLOGY \& HUMANITY, pp. 19-20. Available at: http://mpsi.umm.ac.id/files/file/394399 Sakhiyyatus Sa'diyah.pdf.

Shahbaz, A. and Hasan, S. (2017) 'Psychological Distress and Copping Strategies in mother of children with ADHD', International Journal of Scientific \& Engineering Research, 8(10), pp. 1004-1012. Available at: http://www.ijser.org.

Sugiyono. (2015). Metode Penelitian Kuantitatif Kualitatif dan RED. Bandung: Alfabeta.

Tripathi, N. (2015) 'Parenting Style and Parents' Level of Stress having Children with Autistic Spectrum Disorder (CWASD): A Study based on Northern India', Journal of Neuropsychiatry, 1(1), pp. 1-8. doi: 10.4172/Neuropsychiatry.1000107.

Veague, H. B. (2010). Autism. New York: Infobase Publising.

Weiss, J. A., Wingsiong, A. and Lunsky, Y. (2014) 'Defining crisis in families of individuals with autism spectrum disorders', Autism, 18(8), pp. 985-995. doi: 10.1177/1362361313508024. 